\title{
Efecto in vitro de la acetamida furánica bromada sobre aislados de Salmonella enterica de aves
}

\section{In vitro effect of furan acetamide bromide on Salmonella enterica isolates from chickens}

\author{
Osmaida Estrada Cutiñoa, Ana Carvajalb, Pedro Rubio Nistalb, Lucía Fuentes Jiménezc, \\ Mariano Arean Silveraa, Manuel Almeida Saavedraa, Osvaldo Vallejo Magallanesa, \\ Waldo Ramírez Sáncheza, Ivan Garcia Zaldívara, Vladimir Barrios González ${ }^{b}$
}

\begin{abstract}
RESUMEN
Dentro del género Salmonella, la especie Salmonella enterica, subsp enterica es una de las de mayor interés por su efecto patógeno sobre los animales. El trabajo se realizó con el objetivo de evaluar el efecto in vitro de la acetamida furánica bromada (AFB) sobre Salmonella enterica aviar. La AFB se obtuvo en el Centro de Bioactivos Químicos de la Universidad Central de las Villas, Cuba. La actividad antimicrobiana del producto sobre los aislados de Salmonella entérica se determinó por el método de macrodilución en caldo, según el "National Comité for Clinical Laboratory Standards", NCCLS, documento M7-A2. La concentración letal mínima se determinó según NCCLS, documento M26-A, 1999. Las pruebas bioquímicas y serológicas confirmaron la presencia de Salmonella gallinarum en el $100 \%$ de las muestras. Los valores de la mínima concentración inhibitoria (MCI) y mínima concentración bactericida (MCB) de la AFB fueron ambas de $\mathbf{1 2 . 5} \mathbf{~ m g / m l}$, para las cepas de Salmonella gallinarum y "American Type Culture Collection" de E. coli. Se concluye que la MCI y MCB de la Salmonella enterica frente a la acetamida furánica bromada in vitro fue de $12.5 \mathrm{mg} / \mathrm{ml}$, demostrando la acción bactericida del producto.
\end{abstract}

PALABRAS CLAVE: Acetamida, Aves, Bromada, Furánica, Salmonella.

\begin{abstract}
Salmonella enterica subsp. enterica is one of the most interesting bacteria because of its pathogenic effect on animals. The objective of the present study was to evaluate the in vitro effect of furan acetamide bromide (FAB) on avian Salmonella enterica. FAB was obtained from the Centro de Bioactivos Químicos of the Universidad Central de las Villas, Cuba. The antimicrobial activity of the product against Salmonella enterica isolates was determined by the broth macrodilution method, according to the Committee for Clinical Laboratory Standards (NCCLS), document M7A2. The minimum lethal concentration was determined by NCCLS, document M26-A, 1999. The biochemical and serological tests confirmed the presence of Salmonella gallinarum in $\mathbf{1 0 0} \%$ of the samples. The minimum inhibitory concentration (MIC) and minimum bactericidal concentration (MBC) values of FAB were $12.5 \mu \mathrm{m} / \mathrm{ml}$ for Salmonella gallinarum and American Type Culture Collection (ATCC) of E. coli. It is concluded that MIC and MBC of Salmonella enterica against in vitro effect of furan acetamide bromide was $12.5 \mu \mathrm{g} / \mathrm{ml}$, demonstrating the antimicrobial activity of the product.
\end{abstract}

KEY WORDS: Acetamide, Chickens, Bromide, Furan, Salmonella.

La salmonelosis es una enfermedad infecciosa, contagiosa, de curso agudo o crónico propio de las aves domésticas y silvestres, jóvenes o adultas; el período de incubación es muy
Salmonellosis is an infectious, contagious and acute or chronic disease, frequently observed in young and adult wild and domestic birds. The incubation period varies greatly and ranges

\footnotetext{
Recibido el 3 de mayo de 2013. Aceptado el 26 de noviembre de 2013.

a Departamento de Sanidad Animal. Facultad de Medicina Veterinaria. Universidad de Granma. Cuba. oestradac@udg.co.cu. Correspondencia al primer autor.

b Departamento de Sanidad Animal. Facultad de Veterinaria. Universidad de León. España.

c Instituto Superior Tecnológico del Oriente del Estado de Hidalgo. Apan, Hgo. México.
} 
variable y oscila entre 2 a 4 días, existiendo dos tipos de salmonelosis: Pullorosis, producida por la Salmonella pullorum, afectando a los animales jóvenes, caracterizada por inapetencia, debilidad a las caídas, plumas erizadas, diarreas de color blancuzco, así como congestión hepática y pulmonar; y la Tifoidea aviar producida por Salmonella gallinarum, con síntomas de diarreas fétidas, de color amarillenta-verdosa, pérdida del apetito, debilidad, aumento de la infertilidad e incubabilidad del huevo y focos necróticos en hígado y corazón además de esplenomegalia, los pulmones se encuentran edematosos y congestionados; en ponedoras los ovarios presentan procesos degenerativos(1).

La prevención o el control de enfermedades infecciosas son de vital importancia en la moderna industria avícola, constituyendo la higiene y el saneamiento los principios básicos para evitar y controlar dichas patologías. Sin embargo, estas medidas por separado, no son suficientes, por lo tanto, es un compromiso contar con un manejo sano incluyendo medidas profilácticas y terapéuticas(2).

Los antibióticos utilizados de forma oportuna, por las vías más convenientes y en dosis terapéuticas, brindan un extraordinario beneficio para los animales y el hombre. No obstante, cada día son más las voces de científicos e investigadores que alertan acerca de los peligros que engendra para la humanidad el uso de dosis inadecuadas de los antibióticos(3).

El Grupo de Química y Medicamentos de la Universidad de Granma, Cuba, hoy convertido en el Centro de Estudios de Química Aplicada (CEQA) ha venido trabajando desde el año 1985 en coordinación con el Centro de Bioactivos Químicos (CBQ) de La Universidad Central de las Villas, en la obtención de productos potencialmente bioactivos, entre los que se destaca la acetamida furánica bromada (AFB), que es una sustancia bioactiva, de forma similar a lo reportado en la patente norteamericana(4) que trata sobre las aplicaciones industriales del 2-(2-bromo-2- between 2 and $4 \mathrm{~d}$. There are two types of salmonellosis: pullorum disease of chickens, caused by Salmonella pullorum, which affects young animals and is characterizes by lack of appetite, weakness, ruffled feathers, whitish diarrhea, as well as liver and pulmonary congestion; and avian typhoid caused by Salmonella gallinarum, with symptoms of fetid yellowish-green diarrhea, lack of appetite, weakness, increased infertility and low hatchability, necrotic foci in liver and heart. Besides splenomegaly, there is pulmonary congestion and oedema; in egg-laying chickens, ovaries show degenerative processes(1).

Control and prevention of infectious diseases are vitally important in modern poultry industry, being hygiene and sanitation the basic principles for avoiding and controlling such pathologies. However, these measures taken alone, are not enough; therefore, commitment of proper management including prophylactic and therapeutic measurements are needed(2).

Antibiotics used in a timely manner, by convenient routes and at therapeutic doses, provide a significant benefit for animals and humans. Nevertheless, every day there are more scientific research workers that warn against the danger that represents the use of improper dosages of antibiotics(3).

The chemistry and medication group of the Universidad de Granma, Cuba, which has been turned into the Centro de Estudios de Química Aplicada (CEQA), has been working since 1985 in coordination with the Centro de Bioactivos Químicos (CBQ) of the Universidad Central de las Villas, in the development of potentially bioactive products, among them: furan acetamide bromide (FAB), which is a bioactive substance, similar as the reported in the US patent $(4)$ that deals with industrial applications of 2-(2-bromo-2-nitroethane)-furan C, considered as a potent antibacterial and antifungal substance, with the following chemical composition: 
nitroetenil)-furano C como potente bactericida y fungicida, con la siguiente composición química:

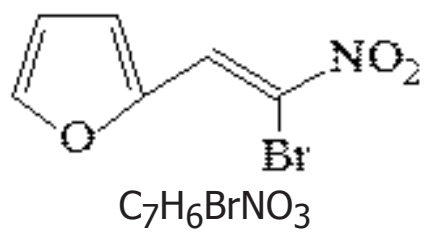

En correspondencia con estos resultados biológicos tan alentadores, se comenzaron los estudios preliminares de toxicidad de la AFB con vistas a determinar su dosis letal media (DL-50 ) y de acuerdo con el trabajo realizado se obtienen los siguientes valores: a) Dosis letal media $\mathrm{DL}-50=1,879 \mathrm{mg} / \mathrm{kg}$ de peso vivo usando como vehículo aceite de maní por vía oral en ratones Balb/c. DL-50 igual a 3,000 mg/kg de peso vivo por vía oral utilizando como vehículo goma tragacanto en ratones OF-1.

Con estos resultados y teniendo presente la clasificación comúnmente empleada para referir la toxicidad inicial de una sustancia, se puede plantear que la AFB es muy poco tóxica. Sin embargo aún no se han realizado estudios relacionados con el mecanismo de acción del producto, ni cómo actúa a nivel de la célula. El objetivo de este trabajo fue determinar el efecto in vitro de la Acetamida Furánica Bromada sobre aislados de origen aviar de Salmonella enterica.

Se tomaron 50 pollitas de inicio ponedoras, línea $\mathrm{L}_{33}$, de 2 días de edad, pertenecientes a la Empresa avícola de Granma, Cuba, se sacrificaron según las normas de bienestar animal para aves y se procesaron en el Centro de Epizootiología y Diagnóstico Veterinario de la provincia de Holguín.

Los aislados confirmados fueron caracterizados mediante pruebas bioquímicas y sueros específicos frente a los principales serogrupos de Salmonella enterica: D, B, $C_{2}$ y $E_{\text {, empleando }}$ los antisueros comerciales procedentes de los laboratorios Finlay (NC: $38-02-13,1991$ ).

La AFB se obtuvo mediante la metodología descrita por Almeida(5), en el Centro de

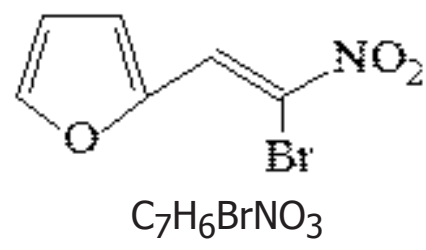

Further supporting this encouraging biological results, preliminary $F A B$ toxicity studies were conducted in order to determine its median lethal dose (LD-50), obtaining the following values: a) Median lethal dose $L D-50=1,879$ $\mathrm{mg} / \mathrm{kg}$ live weight, using oral peanut oil as excipient in Balb/c mice; b) LD-50 equal to $3,000 \mathrm{mg} / \mathrm{kg}$ live weight by oral route, using tragacanth gum as excipient in OF-1 mice.

With these results and having the classification commonly used for referring the initial toxicity of the substance, it can be posed that FAB is highly toxic. However, there are no studies related to the action mechanism of the product, or how does it acts at cellular level. The objective of this study was to determine the in vitro effect of furan acetamine bromide on Salmonella enterica isolates from avian origin.

A total of $50,2-d$ old, $L_{33}$ laying chickens, belonging to the Empresa Avícola de Granma, Cuba were obtained. They were slaughtered according to the animal welfare regulations for birds and were processed at the Centro de Epizootiología y Diagnóstico Veterinario of Holguín province.

Once corroborated, the isolates were characterized by biochemical tests and specific sera against the main serogroups of Salmonella enterica D, B, C 2 and $E$, using the commercial antisera from the Finlay Laboratory (NC: 38 - $02-13,1991$ ).

FAB was obtained by the methodology described by Almeida(5), at the Centro de Bioactivos Químicos of the Universidad Central de las Villas, Cuba, and a solution was prepared with $97 \%$ purity degree and $970 \mu \mathrm{g} / \mathrm{mg}$ power, at a concentration of $1 \%$.

A pure culture of Salmonella enterica type D was seeded onto a Muller-Hinton agar plate 
Bioactivos Químicos de la Universidad Central de las Villas, Cuba, con un grado de pureza del $97 \%$ y una potencia de $970 \mu \mathrm{g} / \mathrm{mg}$ se preparó una solución a una concentración al 1\%.

Se partió de un cultivo puro de Salmonella enterica tipo $\mathrm{D}$ a partir de aislados de campo, el cual se sembró en placas de Agar Muller Hinton durante $24 \mathrm{~h}$ a $37{ }^{\circ} \mathrm{C}$ en aerobiosis. Las colonias, crecidas se resuspendieron en una solución salina isotónica $(0.85 \%)$ en tubos estériles de vidrio $(2 \mathrm{ml})$ hasta alcanzar la turbidez equivalente al patrón de 0.5 a 1 de la escala McFarland, correspondiendo con una suspensión equivalente de 1 a $2 \times 10^{8} \mathrm{ufc} / \mathrm{ml}^{-1}$ para una cepa de control recomendada por el Clinical Laboratory Standars Institute (CLSI)(5) de E. coli ATCC 25922. Obtenida la concentración bacteriana deseada, se realizó una dilución 1:500 (10 $\mu \mathrm{L} / 4990 \mu \mathrm{L})$ en el caldo Mueller Hilton y se mezcló en vórtex durante $15 \mathrm{seg}$, alcanzándose una concentración de 1 a $2 \times 10^{5} \mathrm{ufc} / \mathrm{ml}$. Desde la preparación del inóculo hasta su distribución en los tubos se efectuó en los 15 min siguientes.

Partiendo de la solución madre de AFB se prepararon diluciones dobles seriadas con una concentración inicial elevada de 131,072 $\mu \mathrm{g} / \mathrm{ml}$ hasta una concentración final de $512 \mu \mathrm{g} / \mathrm{ml}$. En todos los casos se realizaron tres réplicas de cada tratamiento y los respectivos testigos: negativo (medio de cultivo sin inocular) y positivo (medio de cultivo inoculado sin AFB). Además se comprobó la pureza de la suspensión del inóculo subcultivando alícuotas en placas de agar Muller Hinton y se incubó simultáneamente.

La Concentración Mínima Inhibitoria (CMI) se determinó como la menor concentración de la AFB que inhibió el crecimiento visible del microorganismo.

La Concentración Mínima Bactericida (CMB), se determinó tomando $100 \mu \mathrm{l}$ de cada tubo de las concentraciones de ensayo donde no se observó crecimiento y se añadieron en placas con medio Muller Hinton incubándose de 18 a 24 h a 37 (aerobiosis incubation, $24 \mathrm{~h}$, at $37^{\circ} \mathrm{C}$ ). The colonies were resuspended in an isotonic saline solution $(0.85 \%)$ in sterile glass vials $(2 \mathrm{ml})$ to achieve a turbidity equivalent to the pattern of 0.5 to 1 in a McFarland standard, corresponding to a suspension equivalent to 1 to $2 \times 10^{8} \mathrm{cfu} /$ $\mathrm{ml}$ for a control strain recommended by the Clinical Laboratory Standards Institute (CLSI)(5) of $E$. coli ATCC 25922. Until the desired concentration was reached, a 1:500 dilution (10 $\mu \mathrm{L} / 4990 \mu \mathrm{L}$ ) was performed in Mueller Hinton broth and was mixed in vortex for $15 \mathrm{sec}$, achieving a concentration of 1 to $2 \times 10^{5} \mathrm{cfu} /$ $\mathrm{mL}$. Preparation of inoculum and its distribution in vials lasted $15 \mathrm{~min}$.

Starting from FAB stock solution, serial twofold dilutions were made with a high initial concentration of $131,072 \mu \mathrm{g} / \mathrm{mL}$, achieving a final concentration of $512 \mu \mathrm{g} / \mathrm{mL}$. In all cases, three replicates of each treatment and their respective controls: negative (non-inoculated culture medium) and positive (inoculated culture medium) were performed. Also, purity of the inoculum suspension was tested, subculturing aliquots on Muller Hinton agar and incubating simultaneously.

The minimum inhibitory concentration (MIC) was determined as the lowest concentration of FAB that inhibited the visible growth of the microorganism.

The minimum bactericidal concentration (MBC) was determined taking $100 \mu \mathrm{l}$ from each vial of the assay concentrations where no growth was observed and were added on Muller Hinton agar plates, incubating for 18 to $24 \mathrm{~h}$ at $37^{\circ} \mathrm{C}$. The colony count was carried out by a colony counter; those concentrations with viable colonies $>10 \mathrm{cfu} / \mathrm{mL}$, where an antimicrobial effect was observed, were chosen.

Data of Salmonella isolation in each organ were analyzed using the multiple proportions test for determining the most affected organs $(P<0.05)$. Analyses were conducted using the Statistica for Windows, version 8 (StatSoft, Tulsa, OK). 
${ }^{\circ} \mathrm{C}$. El conteo de colonias se realizó mediante un contador de colonias y se elegieron aquellas concentraciones con crecimiento de colonias viables $>10$ UFC ml-1 donde se evidenció un efecto bactericida.

Los datos del aislamiento de salmonella en cada órgano se analizaron con la prueba de proporciones múltiples para determinar los órganos más afectados $(P<0.05)$. Los análisis se realizaron con el paquete estadístico "Statistica for Windows", versión 8.0 (StatSoft, Tulsa, OK).

Las pruebas bioquímicas y serológicas demostraron la presencia de Salmonella en el $87.3 \%$ de los cultivos obtenidos, al procesar 300 muestras recogidas en 50 pollitas. Además, se observó diferencia significativa entre la cantidad de muestras positivas y negativas, evidenciándose los mayores valores de positividad en hígado, bazo, pulmón y saco vitelino, siendo este último el más infectado (Cuadro 1).

La caracterización serológica mostró que el serogrupo $\mathrm{D}$ era el mayormente identificado $(61.24 \%)$, seguido en orden descendente por el E $(19.3 \%)$, B $(15.21 \%)$ y el C $(11.33 \%)$.

La CMI y CMB de la AFB frente a la cepa ATCC 25922 de E. coli y Salmonella del serogrupo D, resultaron ser similares, alcanzando un valor de $12.5 \mathrm{mg} / \mathrm{ml}$ para ambos microorganismos no observándose diferencia significativa entre los valores de CMI y CMB de las cepas estudiadas, demostrando la capacidad antimicrobiana del producto contra Salmonella entérica y E. coli.

Las pruebas bioquímicas y serológicas empleadas corroboraron la presencia de Salmonella en el $100 \%$ de las muestras, alcanzándose los mayores valores de aislamiento en hígado, bazo y saco vitelino. Estos resultados coinciden con otros trabajos(6) donde se considera a la salmonelosis como una denominación genérica de los procesos
The biochemical and serological tests demonstrated Salmonella presence in $87.3 \%$ of the cultures, when processing 300 samples collected from 50 chickens. Also, significant difference was observed between the quantity of positive and negative samples, exhibiting the greatest values of positivity in liver, spleen, lung and yolk sac, being the latter the most affected (Table 1). Serological characterization showed that serogroup $D$ was mostly identified $(61.24 \%)$, followed in descending order by $\mathrm{E}$ (19.3\%), B (15.21\%) and C (11.33\%).

On the other hand, MIC and MBC of FAB against E. coli strain ATCC 25922 and Salmonella serogroup $D$, resulted similar, reaching a value of $12.5 \mu \mathrm{g} / \mathrm{mL}$ for both microorganisms (Table 2), showing no significant differences between MIC and MBC values of the strains studied, demonstrating the antimicrobial capacity of the product against Salmonella enterica and E. coli.

The biochemical and serological tests corroborated Salmonella presence in $100 \%$ of the samples, reaching the greatest values of isolation in liver, spleen and yolk sac. These results coincide with other studies(6) where Salmonella is considered a generic denomination of the processes produced by related bacteria in the genus Salmonella, which receives a specific name in the case of particular clinical conditions such as typhoid fever.

Cuadro 1. Hallazgos de Salmonella en las muestras trabajadas

Table 1. Findings of Salmonella in samples taken

\begin{tabular}{lcccc}
\hline Sample & Total & Positives & Negatives & $(\%)$ \\
\hline Heart & 50 & $37^{\mathrm{a}}$ & $13^{\mathrm{b}}$ & 74 \\
Liver & 50 & $45^{\mathrm{a}}$ & $5^{\mathrm{b}}$ & 90 \\
Spleen & 50 & $47^{\mathrm{a}}$ & $3^{\mathrm{b}}$ & 94 \\
Intestine & 50 & $40^{\mathrm{a}}$ & $10^{\mathrm{b}}$ & 80 \\
Yolk sac & 50 & $48^{\mathrm{a}}$ & $2^{\mathrm{b}}$ & 96 \\
Lung & 50 & $45^{\mathrm{a}}$ & $5^{\mathrm{b}}$ & 90 \\
Total & 300 & $262^{\mathrm{a}}$ & $38^{\mathrm{b}}$ & 87.3 \\
\hline
\end{tabular}

a,b Values lacking a common superscript differ $(P<0.05)$. 
producidos por bacterias del género Salmonella, la cual adquiere nombre específico en el caso de cuadros particulares como sucede en la fiebre tifoidea.

Los valores alcanzados de CMI y CMB de la acetamida frente a cepas ATCC 25922 de $E$. coli y Salmonella del serogrupo $D$, indican que es una sustancia bioactiva, que tiene una acción bactericida y fungicida potente, y que su efecto concuerda con el valor obtenido en otros trabajos(7) además al evaluar su eficacia frente a cepas de Staphylococcus aureus y Cándida albicans. Además, este valor de CMI es superior a los umbrales reportados por otros autores para diferentes antibióticos.

Estos resultados pueden deberse, a que la AFB tiene un efecto bactericida que además se corroboró al evaluar cepas de E. Coli, Cándida Albicans, Pseudomona aureginosa, coincidiendo con otros autores(6), los cuales consideran que los valores de CMI y la CMB obtenidas en antibióticos considerados como bactericidas, habitualmente difirieren en una o dos diluciones.

Así mismo otros autores(8), plantean que la susceptibilidad de las cepas testigo frente a los antibióticos de uso convencional, el halo oscila entre 16 a 23; en el presente estudio el halo de inhibición de la AFB, está dentro del rango de la zona de inhibición obtenida por estos autores con respecto a las cepas testigo con los diferentes antibióticos, e incluso para algunos antibióticos está por encima.

Sin embargo otros autores $(9)$ corroboraron que en 150 cepas $S$. typhimurium serovar, aisladas entre 1980 y 1984 en Normandía, 101 mostraron resistencia múltiple frente a los antibióticos. Por otra parte, Kirby(10) señaló que en Inglaterra en 14,400 casos, el $52 \%$ correspondió a $S$. typhimurium, exhibiendo una resistencia múltiple a los antibióticos usuales. De igual forma se ha señalado(11) que en 2,000 aislamientos realizados desde 1959 en Holanda, se comprobó resistencia múltiple a las drogas, y que en el caso de $S$. typhimurium y serovar Dublin
The MIC and MBC values achieved in acetamide against E. coli strain ATCC 25922 and Salmonella serogroup $D$, show that it is a bioactive substance, has potent bactericidal and antifungal action and its effect concurs with the values obtained in other studies(7). Furthermore, when evaluating its effectiveness against Staphylococcus aureus and Candida albicans, this MIC value exceeds the thresholds reported by other authors for different antibiotics.

These results may well be because $F A B$ has bactericidal effect that was also corroborated when assessing E. coli, Candida albicans and Pseudomona aeruginosa, coinciding with other authors(6) who consider that MIC and MBC values obtained in bactericidal antibiotics usually differ in one or two dilutions.

Likewise, other authors(8) pose susceptibility of control strains against conventional antibiotics, with a halo range of 16 to 23 . In the present study, FAB inhibition halo is inside the inhibition zone obtained by these authors, with regard to susceptibility of control strains against different antibiotics and even above some antimicrobials.

However, other authors $(9)$ confirmed that in 150 S. enterica serovar Typhimurium, isolated between 1980 and 1984 in Normandy, 101 samples showed multiple resistance against antibiotics. On the other hand, Kirby(10) pointed out that $52 \%$ of 14,400 cases of $S$. Typhimurium in England exhibited multiple resistance to antibiotics. It has also been reported that in 2,000 isolations carried out since 1959 in Holland, multiple resistance to drugs was proven and in the case of $S$. serovar Typhimurium and Dublin isolates, increased resistance was observed since 1972.

Other authors(12) found that when conducting antibiogram studies with $412 \mathrm{~S}$. Dublin isolates, $100 \%$ resulted sensitive to streptomicyn. However, the performance of the same serovariant strains has varied. In the case of 208 S. Typhimurium isolates, $58 \%$ were sensitive to streptomicyn and kanamicyne. 
aisladas, se apreció incremento en la resistencia desde 1972.

Otros autores(12) encontraron que al realizar estudios de antibiograma con 412 cepas de $S$. dublin aisladas, resultaron susceptibles a la estreptomicina el $100 \%$. Sin embargo, el comportamiento de la misma serovariante ha variado. En el caso de la S. typhimurium de 208 aislamientos, fueron susceptibles a la estreptomicina y a la kanamicina el $58 \%$.

También se comprobó un aumento progresivo de la salmonelosis(13) pero además un incremento de la resistencia a los antibióticos de $35 \%$ entre 1977 y 1978 , al $64 \%$ entre 1984 y 1985 . En un inicio la resistencia fue a tres antibióticos, pero ya en 1985 de 98 aislamientos 47 fueron resistentes a cinco y 51 a seis. En todos los casos se apreció resistencia a la estreptomicina, al cloranfenicol y a la nitrofurantoína. Así mismo en estudios realizados en 300 cepas aisladas en 29 países, comprobaron que todas las cepas susceptibles a los antibióticos eran libres de plásmidos específicos presentes en cepas resistentes(14).

Se ha demostrado(15) que el $60 \%$ de las Salmonellas aisladas, entre las que se encontraban la $S$. typhimurium y la $S$. dublin, mostraron resistencia a los antibióticos más frecuentes. De igual forma16) desarrollaron un trabajo desde 1972 a 1984 tendiente a conocer la susceptibilidad de cepas de $S$. typhimurium, ser. dublin y $S$. enteritidis, y comprobaron un incremento progresivo en la resistencia a las antibióticos y quimioterapéuticos.

Por otra parte se ha corroborado(17) la adquisición de resistencia a antibióticos de cepas de S. arizona a partir de cepas de E. coli resistentes a la kanamicina, tetraciclina y ampicilina, lo que sugiere que la resistencia en las salmonellas puede ser adquirida a partir de líneas de $E$. coli resistentes.

Se plantea que el cloranfenicol es desde hace tiempo la droga de elección en el tratamiento
A progressive increase of salmonellosis and increased resistance of $35 \%$ to antibiotics between 1977 and 1978, and $64 \%$ between 1984 and 1985 was also found. Initially, there was resistance to three antibiotics, but in 1985, 47 out of 98 isolates were resistant to five and 51 to six antibiotics. All cases showed resistance to streptomycin, chloramphenicol and nitrofurantoin. Likewise, studies carried out in 300 strains isolated in 29 countries, proved that all strains sensitive to antibiotics were free from specific plasmids present in resistant strains(14).

It has been demonstrated(15) that $60 \%$ of Salmonella isolates, including Salmonella serovar Typhimurium and Salmonella serovar Dublin, showed resistance to most common used antibiotics. Likewise(16), a study between 1972 and 1984, aimed at defining the susceptibility of Salmonella serovar Typhimurium, Dublin and Enteritidis, proved that there is progressive increase in antibiotic and chemotherapeutic resistance.

On the other hand, the acquisition of antibiotic resistance of Salmonella subsp. arizonae from resistant $E$. coli strains to kanamycin, tetracycline and ampicillin has been corroborated(17), which suggests that Salmonella resistance may be acquired from resistant $E$. coli lineages.

Since a long time ago, chloramphenicol has been the drug of choice for typhoid and septicemia caused by Salmonella(18), but resistant strains to this drug have appeared. Therefore, antimicrobial sensitivity tests are required, being parenteral ampicillin and trimethoprim/sulphamethoxazole effective clinical alternatives.

It has been reported(19) that enrofloxacin (Baytril $($ ) is the most effective drug; even when medicated on a double dose for a three-week period, Salmonella serovar Thyphimurium can be isolated from chickens $48 \mathrm{~h}$ after. Combined treatment with Baytril ${ }^{\circledR}$ followed by two administration of probiotics, resulted effective in total elimination of Salmonella serovar 
de la fiebre tifoidea y las septicemias por Salmonella(18), pero han aparecido cepas resistentes al cloranfenicol. Por consiguiente se requieren pruebas de sensibilidad antimicrobiana, siendo la ampicilina parenteral y la trimetroprinsulfametaxazol alternativas clínicamente efectivas.

Se ha reportado(19) que la enrofloxacina (Baytril) es la droga más efectiva; aún en dosis doble durante un período de tres semanas, la $S$. typhimurium puede volverse a aislar en $48 \mathrm{~h}$ en pollos. El tratamiento combinado con el Baytril, seguido de la aplicación de flora intestinal por dos veces, resultó efectivo en la eliminación total del estado portador de la $S$. enteritidis en pollos adultos. Sin embargo, usado en aves infectadas el concepto solo provocó reacción significativa en los porcentajes de reaislamiento, pero nunca pudo eliminar el estado portador o la diseminación del agente.

Al evaluar la sensibilidad in vitro de 12 antimicrobianos frente a 32 cepas de Salmonella sp. otros autores(20) obtuvieron mayor resistencia a la estreptomicina; y también se observó resistencia para tetraciclina y triple sulfa (96.8\%), con valores de concentraciones mínimas inhibitorias mayores de $500 \mu \mathrm{g} / \mathrm{ml}$.

Por otro lado(6) identificaron 93 cepas de $S$. entérica subespecie entérica; 52 de contenido cecal y 41 de nódulo linfático ileocecal, evaluándose 15 antimicrobianos por el método de dilución en agar: amikacina, gentamicina, ciprofloxacina, cefalotina, cefotaxima, enrofloxacina, fosfomicina, polimixina-B, tetraciclina, cloranfenicol, estreptomicina, trimetoprima-sulfametoxazol, ampicilina, nitrofurantoína y ácido nalidíxico, observándose mayor resistencia a la tetraciclina en 24 de las 93 cepas, a cloranfenicol en 22, a estreptomicina en 22 a trimetoprima-sulfametoxazol en 20, a ampicilina en 18, a nitrofurantoína y ácido nalidíxico en 3 .

Según algunos autores(21) al estudiar la susceptibilidad de las 20 cepas de Salmonella
Enteritidis carrier state in adult chickens. However, this treatment administered in infected poultry caused a significant reaction in reisolation percentage, but it never eliminated the carrier state or agent dissemination.

When evaluating in vitro sensitivity of 12 antimicrobials against 32 Salmonella sp strains, other authors(20) obtained greater resistance to streptomycin and it was also observed resistance to tetracycline and triple sulfa (96.8\%) with minimum inhibitory concentrations greater than $500 \mu \mathrm{g} / \mathrm{mL}$.

On the other hand(6), they identified $93 \mathrm{~S}$. enterica subsp. enterica strains; 52 from caecum content and 41 from ileocecal lymph node, evaluating 15 antimicrobials by agar dilution method: amikacin, gentamicin, ciprofloxacin, cephalothin, cefotaxime, enrofloxacin, fosfomycin, polimixin-B, tetracycline, chloramphenicol, streptomycin, trimethoprim/sulfamethoxazole, ampicillin, nitofurantoin and nalidixic acid; showing greater resistance to tetracycline in 24 out of 93 strains, to chloramphenicol in 22; to streptomycin in 22 ; to trimethoprim/ sulfamethoxazole in 20; to ampicillin in 18; to nitrofurantoin and nalidixic acid in 3 .

According to some authors(21), when studying the susceptibility of 20 strains of Salmonella group D (movable and immovable) isolated from commercial egg-laying hens in Colombia, they found resistance against 17 available commercial products for poultry; which means that all of the bacteria obtained a percentage that ranged between 22 and $44 \%$. All of this entails great responsibility that generates proper use of antimicrobial products, because its indiscriminating use may generate multidrug-resistant strains.

It is important to take into consideration that in order to ensure good treatment of bacterial intestinal diseases, proper isolation of the etiologic agent, choice of the drug based on knowledge of sensitivity, as well as selection and frequency of the administration route are necessary(3). 
grupo D (móviles e inmóviles) aisladas de ponedoras comerciales en Colombia, encontraron resistencia frente a 17 productos disponibles comercialmente para avicultura; lo que significa que todas las bacterias obtuvieron un porcentaje que varió entre 22 y el $44 \%$. Todo esto conlleva a la gran responsabilidad que genera la correcta utilización de los productos antimicrobianos, ya que su uso indiscriminado puede generar cepas multiresistentes.

Es importante tener en cuenta que para garantizar un buen tratamiento de las enfermedades entéricas de etiología bacteriana es necesario un correcto aislamiento del agente etiológico, la elección del fármaco basado en el conocimiento de la susceptibilidad, así como la selección y frecuencia de la vía de administración a utilizar(3).

La acetamida furánica bromada teniendo presente la clasificación comúnmente empleada para referir la toxicidad inicial de una sustancia, se puede plantear que es muy poco tóxica(5) por tanto esto es un punto de partida importante para su utilización. Las propiedades bactericidas y funguicidas de la AFB, unida a su baja toxicidad abren amplias perspectivas para la aplicación del citado producto como fármaco.

En el trabajo se pudo demostrar las propiedades antibióticas de la AFB, resultados similares con cepas de referencias como son E. coli, St. aureus, Ps. auriginosa y $C$, albicans frente a la Salmonella fueron obtenidos por otros investigadores(22).

Los resultados que aporta la presente investigación tienen gran repercusión, debido a que constituyen una posible opción in vitro para perfeccionar la terapéutica en el tratamiento de la Salmonelosis, al demostrarse su efecto bactericida, ya que esta enfermedad presenta una alta incidencia en la población de ponedoras, en nuestra provincia, causando grandes pérdidas económicas, y por otra parte la disminución de la efectividad de los
Taking into account the commonly used classification to refer the initial toxicity of a substance, it can be posed that FAB is unlikely to be toxic(5); therefore, it is an important starting-point for its use. The bactericidal and antifungal properties of $F A B$, joined with its low toxicity open extensive perspectives of the product as a drug.

In the present study, the antibiotic properties of FAB were demonstrated; similar results with reference strains such as: Escherichia coli, Staphylococcus aureus, Pseudomona aeruginosa and Candida albicans against Salmonella were obtained by other researchers(22).

The results of this study have great impact because they constitute a possible option for the treatment against Salmonella isolates in vitro, by demonstrating its bactericidal effect, since the disease presents high incidence in egg-laying hens in Mexico, causing great economic losses and decreased effectiveness of antimicrobials usually used to treat salmonellosis.

The bactericidal and antifungal properties of FAB should be kept in mind for further in vivo studies, with the aim of achieving greater effectiveness of the product. The biological activity of brominated furans is not always associated with possession bromine atoms in the 5-position of the carbon skeleton of the compound(5).

\section{End of english version}

antimicrobianos usualmente empleados contra esta patología.

Deben considerarse las propiedades bactericidas y fungicidas de la AFB para continuar estudios in vivo, buscando una mayor efectividad del producto. La actividad biológica de los derivados furánicos bromados no siempre está asociada con la tenencia de átomos de bromo en la 
posición 5 del esqueleto carbonado de dicho compuesto(5).

\section{LITERATURA CITADA}

1. Sánchez PA, López A, García SMC, Lamazares PMC, Pérez M, Trujillo G, Sardá R. Enfermedades bacterianas de las aves (Salmonelosis). En: Salud y producción de las aves. Ed. Félix Varela. La Habana 2010:220-228.

2. Malo A. Vacunación efectiva en reproductoras. [en línea] http://72.14.207.104/search?q=cach:De0hex6o4Bk]: www.intervet.com.ve/binaries/84_82149.doc+colera +aviar\&hl=es. 2004. Consultado abril 3, 2006.

3. Fernández AL. Uso de antibióticos en la avicultura. Instituto de Investigaciones Avícolas. Ciudad de la Habana ISBN. 2004. 959-7131-03-X.

4. United States Patent. 5,090,990. Feb.25 1992.

5. Métodos de dilución para determinar la sensibilidad a los antimicrobianos de bacterias que crecen en condiciones aeróbicas. Norma aprobada. Octava edición. M07-A8 29(2 reemplaza a M07-A7 26(2). Clinical and Laboratory Standars Institute. 2009.

6. Rodríguez FEF, Gutiérrez MCB, Puente RVA. Lo que usted debe saber de las Salmonellas y Salmonelosis. Departamento de Sanidad Animal. Microbiología e inmunología. Facultad de Veterinaria. Universidad de León. 1999.

7. Almeida SM. Evaluación preliminar de la actividad biológica de los compuestos sintetizados en síntesis de compuestos potencialmente bioactivos derivados del furoilacetonitrito [Tesis doctorado]. Santa Clara, Cuba. 1994.

8. Thornsberry $C$, Hawkings TM. Procedimiento de prueba de susceptibilidad por dilución en disco de agar, PHS. Atlanta Centro de Control de Enfermedades. 1977.

9. Vaissaire JP, Plateau E, Corbion B, Mirial G, Labroche M. Current status of Salmonellosis in the Fdal. Sc Vet Med Comp 1984;86:123-127.

10. Kirby FD. Surveillance of animal Salmonella infection 19761984. Vet Res 1985;117(18):456-467.
11. Leeuwen WJ, Guinee PAM, Voogd CE, Van Kligeren B. Review of the resistence of Salmonella to antibiotics $\mathrm{Tj}$ Voor Dier Kunde 1986;111(1):9-13.

12. Pérez I. Hallazgos de Salmonella en aves domiciliadas y silvestres. Rev Avicultura 1985;29(3):237.

13. Otner W. Resistence to antibiotic among Salmonella from meat and poultry. Dentsche Veterinae Medizinische Gresellschaft. Ref. 1985;10:224-253.

14. Bulling $E$, Helmuth R. Pathogenicity mechanisms in Salmonella. Ber Munch Tier Mc 1986;99(1):25-27.

15. Ikeda JS, Hirsh DC, Jang SS, Biberstein E. Characteristics of Salmonella Isolated from animals at a Veterinary Medical Teaching Hospital. Am J Vet Res 1986;47(2):332-335.

16. Theys H, Vermenn I, Water J, Crimon A. Antibiotic sensitivity of Salmonella strains isloted from Belgian veal calves during 1982-1984. Vleans Diergences During Tjdschrift. 1985;54(3):382-384.

17. Gast RK, Stephens JF. In vivo transfer of antibiotic resistance to a strain of Salmonella arizona. Poultry Sci 1986;62:2.

18. Sonnenwirth AC, Jarett L. Bacilos, vibrios y espirilos gramnegativos. Métodos y Diagnósticos del Laboratorio Clínico. Tomo 3. La Habana: Ed. Revolucionaria; 1986;19951602.

19. Goren E. Eliminación del estado portador de Salmonella enteritidis mediante el tratamiento con enrofloxacina seguido de la aplicación de microflora intestinal. Rev Avicultura Profesional 1993;10(4):191-192.

20. Sumano LH, Gutiérrez OL. Sensibilidad de diferentes bacterias a enrrofloxacina, tilmicosina y fosfomisina. Farmacología clínica en aves. 3era ed. 2008.

21. Mantilla J, Pulido M. Valoración de la situación actual de explotaciones de ponedoras comerciales con cuadros compatibles con Tifoidea Aviar en Colombia. [Tesis maestría]: Facultad de Medicina Veterinaria. Universidad Nacional de Colombia; 2010.

22. Azahares LE, González O, Sierra G, Medina R, Silveira E, Campa C, Castañedo N. Evaluación de la actividad antimicrobiana "in vitro" del derivado del furfural G.1. Informe Técnico I/1992. Grupo Haemophilus. Centro de Producción e Investigaciones de Vacunas y Sueros. "Instituto Finlay", Ciudad Habana, Cuba; 1992. 